\title{
An Empirical Analysis of the Impact of Gradual Withdrawal of Subsidy on Domestic Consumption of Premium Motor Spirit in Nigeria
} 1977-1999

\author{
Ukah O.C
}

\section{Abstract}

The oil industry is the main backbone of the Nigeria economy. Oil one of the most valuable, versatile and flexible non reproductive, depleting natural resources is Nigeria's major source of foreign exchange earning constituting about $97 \%$ of Nigeria's foreign exchange earning since the 80 's and just above $20 \%-25 \%$ total GDP in the 80 's and $70 \%$ of budgetary revenue. Oil has remained the engine of growth of the Nigerian economy. Over the years the price of petroleum products has been subsidized. However, with effect from September 1986, government decided to gradually withdraw the subsidy on petroleum product. This has fueled the increase in the general price level. The study hypothesized that the withdrawal of subsidy or increase in the price of Premium motor spirit (P.M.S) has no significant effect on the domestic consumption of the commodity P.M.S was found out to be inelastic in demand. Consequently increase in its price has no effect on domestic consumption demand and impact negatively on consumers. Therefore, the Nigerian economy base should be diversified rather than depending solely on the oil sector for sustaining development of the economy.

\section{Introduction}

Faced with severe economic crisis, the Nigerian government adopted various economic measures between 1982 and 1986. These include economic stabilization Act of 1982, National Economic Emergency Act of 1985 and the Structural 
Adjustment Programme. All these were aimed at a sustainable long-term economic growth and development.

The structural adjustment programme (SAP) a much comprehensive reform programme in terms of its scope; breath and depth had four principal aims

The main objectives of SAP include to restructure and diversity the productive base of the economy in order to reduce dependence on the oil sector and on imports. The cardinal measure to achieve included:

(i) Trade Liberalization

(ii) Deregulation of the financial sector

(iii) Rationalization and privatization of public sector enterprises and

(iv) Adoption of appropriate pricing policies (by eliminating subsidies especially from petroleum products and public enterprises)

Arising from this last measure government has over the years since 1986 progressed

from gradual withdrawal of subsidy on petroleum products to appropriate pricing stage resulting in increases in pumps price of these products this has had a severe negative impact on the political economy of Nigeria. It is against this background that this writes up seeks to examine the relationship between domestic consumption demand and subsidy withdrawal on petroleum products. In other words this study attempts to determine that effect of increase in price of petroleum products on the domestic consumption of Premium Motor Spirit (PMS)

This write up aims at providing a basis for analyzing the forces at play in determining petroleum product prices. It also seeks to ascertain whether the economic theory of demand adequately explains the true behaviour of demand structure for petroleum

products in Nigeria. 
Arising from above, it aims at providing a basis to be able to predict and forecast the magnitude of consumption of P.M.S. domestically given the prices of the products. This will help in accommodating future increase in demand, thus avoiding negative shocks in the economy that might erupt e.g. shortages resulting in high cost of transport services, factory closure, and reduction in man hour in productive engagement, labour dispute and output/income

Finally, it seeks to highlight the fact that government would be pricing the products out of the reach of a greater percentage of Nigerians if product prices are uneconomically high just as what happened in the case of Peugeot Automobile of Nigeria (PAN) and Volkswagen of Nigeria (VON) in pricing their products.

To capture impact of subsidy removal on domestic consumption of petroleum product the research question below taken for granted would be verified.

(i) The withdrawal of subsidy or increase in price of petroleum product has on significant effect on the domestic consumption of Petrol (P.M.S)

In order to determine the impact of subsidy withdrawal on the consumption of P.M.S. at home, an econometric estimation model was adopted. Consequently, the OLS method was employed involving the use of multiple regression analysis. However, to obtain a better result autoregressive model was further used.

Crude oil is an oily bituminous liquid. It is often referred to as the black gold. Crude oil is very versatile, flexible and nonreproductive depleting natural resources. It is a mixture of many substances mainly carbon and hydrogen usually referred to as hydrocarbon. Crude oil often called petroleum is the lifeblood of industrialized and many developing countries. A lot of products are derived from crude oil. These products, ranges from paving materials to drip-dry fabrics, engine grease to 
cosmetics. It is use in making products such as aspiring, carpet, curtains, detergents, records, plastic toys and toothpaste. Crude oil got from the earth has been useful to man for over thousands of years before its full value was recognizes in the $18^{\text {th }}$ century. This was the time of invention of automobile engine and paraffin lamp. This created great demand for petroleum fuel-paraffin (kerosene) and petrol (gasoline).

The documentation of the occurrence of the mineral in Nigeria was recorded in. 1903. Petroleum exists in Nigeria as crude oil occurring onshore below the ground at a depth of between $200-300 \mathrm{~m}$ and offshore at a depth of about $200 \mathrm{~m}$ water depth. It exists always, either with associated and nonassociated gas condensates and tar-sand.

In Nigeria, it has been confirmed that petroleum exists in seven prospective basins. These include Dahomy Basin, Niger delta, Anambra basin, Benue through and the lake Chad basin. Tar-send deposits lies in the south-eastern shelf.

According to Iloeje O.C. (1993), Nigeria's proven oil resaves are approximately 21 million barrels. Tar-send estimate is preliminary, however, indications are that about 31 million barrels of oil equivalent exist.

The refining of crude oil is normally done in two major stages. The derivatives of atmospheric and vacuum distillation of Nigeria crude includes:

Gas i. This implies uncondensable gases, methane, ethane, and ethylene, which are

used for combustion within the refinery.

ii. Liquefiable gases, propane and $80 \%$ butane

Gasoline: This is also called Premium Motor Spirit (PMS) or petrol in Nigeria, is used in sparking ignition engines, to dive pleasure cars and transport vehicles. It is believed to be the most widely use or consumed by the rich in the society. 
Kerosene: Two kind of kerosene exist. These are dual purpose kerosene (DPK) used by the generality of the population especially the low-income earners for heating, lighting and cooking. As a result government considers it expedient to reduce the price to the barest minimum. DPK if properly refined yields the second type Automotive Turbine Kerosene (ATK) or Aviation Turbine Kerosene which serves as fuel in the aviation industry.

Automotive Gas Oil (AGO): It is commonly called diesel in Nigeria and used as fuel in diesel engines. AGO is used primarily by the industrial sector in giant generator, trucks, ships, and barges e.t.c. It's pricing by the government is based on the premise that the industrialist needs government backing, consequently, a little lower than the price of PMS on the average.

Other derivatives of crude oil include lubricating oils, waxes, high/low pour fuel oil bitumen/asphalt and miscellaneous products. However, the product yield of Nigeria crude oil consists essentially of the first four.

\section{Crude Oil Products Pricing Domestic Scene}

According to Iwayeme A. (1993), petroleum products prices in the domestic energy market have been under government control since 1973 when she took it over from the industry. The pricing of petroleum products in Nigeria is therefore the sole responsibility of N.N.P.C. (Nigerian National Petroleum Corporation), a federal government parastatal.

Prior to Jan. 1986 the products prices were evaluated on a cost-plus basis at a period when the Naira values was at per with the USA dollar. According to Anyanwu J.(1993) The prices of products refined for domestic consumption was $80 \%$ of the prevailing international market price. The remaining $20 \%$ were the subsidy allowed by government since it is locally exported and processed. Uduebor (1994), stated that the resulting product prices were then in line with import parity level i.e. the 
prices to be paid if all products were imported. The advent of structural adjustment programme (SAP) with the establishment of $2^{\text {nd }}$ tier foreign exchange market (SEFM) in September 1986 altered the status quo between the Naira value and the US dollar. Consequently, these new relationships undermined the initial intention of government as reflects in the petroleum products pricing for domestic market by maintaining subsidy factor at $20 \%$ on the price paid at home. As the Naira depreciates progressively over the years against the major currencies of the world, the subsidy has increased again. This had led to the upward review of prices of petroleum products or gradual withdrawal of subsidy by the government in Jan. 1986, April 1988, June 1989, March 1991, November 1993 and October 1994 and finally in December 1998.

TABLE 1 Official prices petroleum products 1985-1998-N/litre

\begin{tabular}{|l|l|l|l|l|l|l|l|l|l|l|l|}
\hline \multicolumn{9}{|c|}{ N/litre } \\
\hline & 1985 & 1986 & 1987 & 1989 & 1990 & 1991 & 1991 & 1992 & 1994 & 1995 & 1998 \\
\hline $\begin{array}{l}\text { PMS } \\
\text { (Gasoline) }\end{array}$ & .20 & .395 & 0.42 & 0.60 & 0.60 & 0.7 & 0.25 & 3.25 & 11 & 11 & 20.0 \\
\hline $\begin{array}{l}\text { Kerosene } \\
\text { (DPK }\end{array}$ & .105 & 0.105 & 0.15 & 0.15 & 0.4 & 0.5 & 0.5 & 2.75 & 6 & 6 & 17.0 \\
\hline $\begin{array}{l}\text { Kerosene } \\
\text { (ATK }\end{array}$ & .105 & 0.30 & 0.50 & 1.24 & 2 & 1.05 & 1.05 & 5 & 7 & 7 & \\
\hline $\begin{array}{l}\text { AGO } \\
\text { (Diesel) }\end{array}$ & .11 & 0.295 & 0.35 & 0.35 & 0.5 & 0.55 & 0.55 & 3 & 9 & 9 & 19.0 \\
\hline $\begin{array}{l}\text { Fuel oil } \\
\text { (HFO) }\end{array}$ & .023 & 0.19 & 0.3 & 0.3 & 0.4 & 0.55 & 0.55 & 2.5 & 7 & 7 & \\
\hline LPG & .323 & 0.40 & 0.4 & 0.4 & 0.8 & 1.09 & 0.09 & 1.09 & 2.0 & 2.0 & \\
\hline
\end{tabular}

SOURCES: (i) NNPC Lagos. (ii) CBN BULLION VOL 21 No 43. Pp 84-55

iii) Anyanwu et.al (1997). The structure of the Nigerian Economy (19601977)

The government acknowledges the hardship the subsidy withdrawal would cause consumers, appealed for understanding and co-operation of all and sundry. Emphasizing the motives behind it, the following were identified, (i) the need 
to enhance the productive and distributive capacity of oil firms, NNPC and marketers, (ii) generate more revenue for the government, (iii) alien prices of petroleum products with other prices in the economy in line with government deregulation policy, (iv) conserve oil through rationalization in the use of petroleum products and $(\mathrm{v})$ check the activities of smugglers of petroleum products across the country's boarders.

These were basically the reason advances by government through its parastatal NNPC year in year out for the hike in prices of petroleum products.

According to Uduebor (1994), subsidy viewed from a broad perspective means direct or indirect payment, economic concessions or privilege granted by the government to private concerns, public agencies and households in order to promote public objective since it give price advantage over imports. From a restricted point of view, subsidy is payment by government, organizations or individuals to make the price paid by the final consumers lower than production cost of the good or service. The main objective is to alter the outcome of competitive market in the direction consistent with the objectives of public policy. The final effect is that it encourages the growth of industries subsidized and the consumption of the good produced by such industries. Consequently, changes the use to which an economy allocates her scare resources. Petroleum sector of any economy would be subsidized if the government sold the crude oil products (i.e. if the cost of processing a unit of the crude is higher than the market price of same quantity; and if the crude or product is sold in the domestic market at a price level below the price in the international market (opportunity cost of crude).

The determination of the existence of subsidy according to Uduebor (1994), can be establish based on the comparison of the cost structure of petroleum products and the pump price in Nigeria. Two types of cost structure - (i) cost of production 
plus NNPC operational costs and (ii) opportunity cost of crude oil plus NNPC operational costs exist.

A comparison of both costs with pump price of petroleum products in Nigeria is given a detail analysis below. However, data use may be biased upwards in cost guessimation since they were sourced mainly from the NNPC. The Belgore tribunal of enquiry of 1992 exposes this when it was found that cost data submitted by NNPC to the tribunal showed higher cost estimate than the figure previously acknowledged by the organization. In order to muster public support for petroleum products prices increase, the cost of producing a barrel of crude oil, which NNPC admitted earlier to average US $\$ 3.50$, was increased to US $\$ 6.50$ at the tribunal.

The product yield of petroleum from the $4^{\text {th }}$ Port Harcourt, Warri and Kaduna refineries according to Uduebor (1994), on the average amount to $32.16 \%$ of gasoline, $16.16 \%$ kerosene, $24.59 \%$ automotive gas oil and $21.97 \%$ of fuel oil making a total of $94.88 \%$

Therefore, it is estimated that out of the 159 liters in barrel of crude oil, gasoline accounts for 51.1 liters, kerosene 25.7 liters, gas oil 39.1 liters and oil 35.0 liters which sums to up 151.8 liters.

Such products as LPG, bitumen/asphalt, waxes, base oil, burnt coke and flare gas account for the 8.1 litres remaining.

Apart from the insignificant gas and coke, which constitutes wastes, all other products are useful. Implicit from the above is that a barrel of crude oil yield 159 liters of refined useful petroleum products.

In examining the production cost of refined petroleum products any of the two cost structure below could be adopted.

Cost Of Producing Gasoline Plus NNPC Operational Cost: this involves the operational cost incurred by NNPC and wellhead. However, others include NNPC margin computed at $10 \%$ of total cost and marketers' margin. Table 2 illustrates the 
cost structure of producing a barrel of crude oil plus NNPC operational cost including profit margin for NNPC and oil marketers.

\section{TABLE 2}

One barrel of crude oil in Nigeria

Operational costs of items

(i) Refining costs

US\$/barrel

(ii) Distribution

1.81

(iii) Headquarters overheads

(iv) NPA charges

0.62

(v) Depreciation cost

0.01

(vi) Financial charges

0.38

Sub-Total

0.51

(vii) Cost of producing a barrel of oil

Total production and operational cost

(viii) NNPC margin (10\% of total cost)

6.50

(ix) Marketers margin

\section{Grand Total}

Source: Date submitted by the NNPC to the Balgore Tribunal of Inquiry into fuel shortage in 1992.

According to Uduebor (1994), given that

i) Total production and operational cost $=$ US $\$ 14.54$

ii) Naira exchange rate $=\mathrm{N} 22.00=\$ 1.00$ (official Total government ex. Rate)

cost $=\$ 14.54 \times \mathrm{xN} 22.00=\mathrm{N} 319.88 \mathrm{pb}$.

Given also that one barrel of crude oil contains 159 liters.

Cost of producing a liter $=\underline{\mathrm{N} 319.88}=\mathrm{N} 2.01$ 159

A barrel/litre of crude oil contains several varieties of petroleum products. Hence the cost of producing one litter is N2.01, is also the cost of producing all the varieties of petroleum products in a line. Ceteris paribus, using the 1998Autonomous exchange rate of $\mathrm{N} 100.85$ to $\$ 1.00$ and $\$ 25.00 \mathrm{pb}$ 
Total cost of producing a barrel $=\mathrm{N}(100.85 \times 25.00)=\mathrm{N} 2,521.25$

Cost of producing a liter $=\underline{\mathrm{N} 2521.25}=\mathrm{N} 15.86$

159

The 2nd cost structure opportunity cost of Crude Oil plus NNPC operational cost holds that oil and its derivatives a global good, the price anywhere should be an international prices. Consequently, the opportunity cost of crude oil in this case is the price for which the crude oil could have been sold in the international

oil market or the cost of importing crude for refining in Nigeria.

Table 3 illustrates the opportunity cost of crude oil plus NNPC operational cost of one barrel of crude oil in Nigeria.

\section{Items operational cost US\$/Barrel}

(i) Refining cost 1.81

(ii) Distribution 1.65

(iii) Headquarters' overhead

0.62

(iv) NPA charges

0.01

(v) Deprecation costs

0.38

(vi) Financialcharges

0.51

Sub total

4.78

(vii) Crude Oil at international market price 16.50

Total crude oil operation costs

21.23

(viii) NNPC margin ( $10 \%$ of total cost) 2.13 
(ix) Marketers margin

2.13

Grand Total costs

25.54

Source: Data submitted by NNPC to the 1992 Belgore Tribunal on fuel shortages.

Arising form the cost structure in table 3 , the price per/litre can be computed thus:

Grand total cost $=$ US $\$ 25.54$. Naira exchange Rate= N22.00to $\$ 1.00$ (official govt. ex.rate

Total cost $=22.00 \times 25.54=\mathrm{N} 561.88$

Given that one barrel of crude oil $=159$ litres

Cost of producing one litres $=\underline{\mathrm{N}(561.88)}=\mathrm{N} 3.53$

159

Since a litre of crude oil contains a 'basket' of petroleum products, all of which cost N3.53 produce. The cost price of producing each component according to Uduebor (1994) is as follow:

One litre of gasoline about N1.4

One litre of kerosene $\quad 57 \mathrm{k}$

One litre of AGO $87 \mathrm{k}$

One litre of fuel oil $\quad 78 \mathrm{k}$

Similarly, using the 1998 exchange rate of N100.85 to $\$ 1.00$ and $\$ 25.00 \mathrm{pb}$ (AFEM. Rate)

Total cost of producing a barrel $=\$ 34.00 \times \mathrm{N} 100.85=\mathrm{N} 3432.93$

Cost of producing a litre $=\underline{\mathrm{N} 3432.93}=\mathrm{N} 21.59$

159

Accordingly the cost of producing each component runs thus;

One litre of PMS about $=$ N6.94

One litre of AGO about $=$ N5.31

One litre of DPK about= N3.49

One litre of fuel oil about $=\mathrm{N} 4.74$

The costs of producing others are relatively negligible. 
It is crystal clear from tables 2 and 3 that the production costs of various products are higher than their retail prices which prevailed before Nov' 93 price increase but not after. Consequently, the issues of subsidy no longer exist with effect from Nov' 1993 price increase and beyond. (see table)

The crash of the world oil price in 1982 and1986 resulted in severe economic crises for Nigeria. This is because of Nigeria excessive dependence on petroleum exports earning. Crude oil accounted for between $20 \%-25 \%$ of total GDP in the early 80 's $90 \%$ of foreign exchange earnings and $70 \%$ of budgetary revenue. Consequently, the over reliance on oil export revenue which progressively fell short of projected receipts, subjected the Nigerian economy to adverse consequences. This according to lyoha (1996), manifested in internal problems, which included recession, inflation, high unemployment and increasing fiscal deficit, while the external problem included chronic current account and balance of payments deficits, a falling reserve import ratio and an increasing foreign debt stock. worsen the problem of the macroeconomic environment. With the high import dependent nature of the Nigerian economy. It became highly subjected to international trade shocks. As earnings from oil crashed from about US $\$ 25 \mathrm{~b}$ in 1980 to US $\$ 6.4 \mathrm{~b}$ in 1986, trade arrears piled up, and international credit lines drying up, reserve-import ratio hardly adequate enough to finance one month import bill, the country was at the brink of economic collapse. Consequently, to shore up the revenue base of the economy, the government restored to internal upward review of petroleum products prices solely neglecting the participation of other sectors. The pricing therefore is not a true reflection of the demand structure.

Thus as the issue of subsidy become sour and absolute the concept "appropriate pricing" took over. This model based on (the foreign market cost) IMF and World Bank sponsorship is doubtful. It has been argues that Nigerian naturally endowed 
with oil, should avail her citizens the gains and benefits of a producer nation. The adoption of the IMF-World Bank model does not distinguish between oil importer and Nigerian consumers of petroleum products as both plays the same price for crude oil. It is important to note that citizens of Nigeria earn their income in Naira and not in US\$. In the light of the above it is wrong to match what Nigerians should pay to what foreigners pay for the same product without recognizing the ability to pay and even cost of transportation across the international boundaries.

\section{Local Consumption of Petroleum Products}

(a) Crude oil local consumption by the refineries has grown significant since the civil war. Delivery level rose from $7.61 \mathrm{mb}$ in 1970 progressively to $20.98 \mathrm{mb}$ in 1973 fluctuated downwards through 1974 to $17.66 \mathrm{mbin} 1975$. This was caused by breakdown and eventual temporary closure of Port-Harcourt refinery. It fluctuated between 1976 and 1977 but increased continuously from $32.7 \mathrm{mb}$ between 1979 to $62.3 \mathrm{mb}$ in 1982 . Again between 1983 and 1987 there was downward fluctuation. It rose to $96.0 \mathrm{mb}$ in 1993 and by 1994, there was decline to $88.1 \mathrm{mb}$ and in 1995 it peak at $99.73 \mathrm{mb}$. As a percentage of total production/ deliveries to the refineries average $30.15 \%$ in the period $1970-1980$ increased by an average of $11.26 \%$ between $1981-1990$ and to over $12.9 \%$ of the total production in 1991-1995.

(b) The local consumption of petroleum products by Nigeria has a direct relationship with the economic and income growth. According to Ojo and Adebusuyi, (1996) the picture has been reinforced by their low prices. The bulk of the consumption has been in P.M.S. or gasoline, AGO or diesel and dual purpose kerosene or DPK. These products account for more than $60 \%$ of total home consumption of petroleum products, They further asserted that PMS and AGO are the major fuel for the road 
transports sector as well as for small to medium sized electricity generating plants for power supply in houses and rural area detached from NEPA. They equally serve as stand by power sources in industries. While AGO is mostly use on heavier diesel engines, P.M.S. is used in vehicles small electricity generating plants drives for compressor e.t.c.

In 1981 the local consumption amounted to 13.7 million tones, this increased by $2.0 \%$ to 14.2 million tones in 1982. There was a downward fluctuation from 1983 through 1987 to 7.7 million tones in 1990 . It however increased to 8.1 million tones and $10.7 \mathrm{~m}$ tones in 1991 and 1992 respectively. Since 1993 the trend has been declining from 8.6, 7.9 and 7.7 million tones in 1993, 1994 and 1995 accordingly.

Ojo and Adebusuyi (1996) pointed out that decline in domestic demand is attributed to the problems of distribution, storage inadequacies and increase in prices which has tended to eliminate wastes. In his down to earth analysis of domestic consumption and pricing of some petroleum products in Nigeria, Jaja (1997), asserted that the obvious reduction in petroleum products subsidy or the recent price increase affected their demand adversely.

However, the scenario has been a fluctuating trend in consumption pattern of petroleum products locally. This could be attributed mainly to the gradual withdrawal of subsides on these products and the accompanying upward review of wages and salaries of workers to pacify the citizens.

\section{Methodology/Model Specification and Estimation}

This sector deals with the specification and estimation of an econometric model of demand for PMS in Nigeria. The structural modeling approach employed in this study describes the structural relationship between economic variables (prices, income-GDP) and demand (consumption) as a guide for inferring the impact of subsidy withdrawal on petroleum 
products on the domestic consumption of PMS Consequently a disaggregated analysis employing multiple regression equation, to reflect the functional relationship of subsidy withdrawal (price increase) on domestic consumption.

In other to capture the essential impact of subsidy withdrawal on domestic consumption of petroleum products- P.M.S. the Keynesian consumption function/model would be employed. The model runs thus,

Con PMS $=\mathrm{F}(\mathrm{Y}, \mathrm{PPMS}, \mathrm{PAGO}) \quad$ -

Con PMS $=a_{0}+a_{1} Y_{t}+a_{2} P P M S+a_{3} P A G O+E_{t}-$ Where $a_{1}>0, a_{2}<0, a_{3}>0$

Con PMS = Consumption of premium motor spirit

$\mathrm{Y}_{\mathrm{t}}=$ income- Real GDP at 1984 factor cost

$\mathrm{PPMS}=$ Price of Premium motor spirit

PAGO $=$ Price of Automotive Gas oil

$\mathrm{E}_{\mathrm{t}}=$ error term

$a_{0} . a_{1}, a_{2}, a_{3},=$ Parameters of the model and price elasticities.

\section{Model Estimation}

An econometric approach was adopted in estimating the model and the log of the variables were taking. This is to help determine also the elasticity co-efficient of the variables and its implication. Thus,

In Con $P M S=a_{1}+a_{1} 1 n Y_{1}+a_{2}$ InPPMS $+a_{3} \ln P A G O+E_{t}$ (c)

\section{Empirical Result and Discussion}

Here the results of the estimated regression equations specified in section three is presented and analyzed. Data employed runs in two stages from 1977-1986 before SAP 19871997. Consequently, the estimated models run thus:

Stage I: $1977-1986$

1. In Con PMS $=-30.135+1.919 Y-1.270 P P M S+0.643 P A G O$ 


$$
\begin{aligned}
& \begin{array}{llll}
(19.7044) & (0.8325) & (0.9644) & (0.7626)
\end{array} \\
& \mathrm{t}=(-1.5294), \quad(2.3053), \quad(-1.3175), \quad(0.8436) \\
& \mathrm{R}^{2}=0.7305, \mathrm{R}^{2} \text { adjusted }=0.5148, \mathrm{~F}(4,5)=3.3875 \text {. } \\
& \text { D.W. }=0.9488
\end{aligned}
$$

Stage II: $1987-1997$

2. In Con PMS $=13.795+0.0512 Y-0.5907 P P M S+0.505 P A G O$

$$
\mathrm{t}=\left(\begin{array}{lllr}
(1.3954) & (0.05321) & (0.3093) & (0.297) \\
(9.886) & (0.9678) & (-1.9302) & (1.6905)
\end{array}\right.
$$

$\mathrm{R}^{2}=0.6226$, F-statistic $\mathrm{F}(4,5)=2.4745$. D.W $=2.069$

Considering equation 1 and 2 the presence of serial correlation necessitated the use of first order autoregressive model to improve on the OLS results.

The results obtained from equation 1 shows that model is a good fit with $R^{2}=73.1 \%$ and $R^{-2}=51.5 \%$. This implies that at least $51.5 \%$ of the variation in the model is attributed to the explanatory variables.

The F-statistics $F(4,5)=3.3875<F$ observed $=5.19$. This shows that model is not significant at $5 \%$ level meaning that there is no significant linear relationship between the four independent variables taken together and the aggregate consumption of P.M.S.

Considering the explanatory power of the individual variable none of the variable is a significant determinant of the consumption of P.M.S. The estimated equation proves that a unit increase in the consumption of P.M.S. is partly generated by a fall in price of P.M.S. by N1.27.

Theoretically the a-priori signs apart from income are appropriate. With D.W. statistic $=1.596$, the presence of autocorrelation was corrected adopting the second order autoregressive scheme.

The results obtained in equation 2 proves that the model is fairly a good fit with $\mathrm{R}^{2}=62.3 \%$ indicating that $62.3 \%$ of the variation in the model is caused by the independent variables. 
The F-statistics $F(4,6)=2.4745<F$ observed $=4.53$ implies that the model is not significant at $5 \%$. Consequently, there is no significant linear relationship between the independent variables taken together and the aggregate consumption of PMS from 1987- 97. Again none of the independent variable is significant at $5 \%$ level.

The estimated regression equation indicates that a unit increases in the consumption of PMS is generated by a fall in price of PMS by $59 k$, increase in income by 0.05 units and price of AGO by $5 \mathrm{k}$.

With D.W. statistics $=2.0698$, the presence of autocorrelation was ratified.

Conclusively, the results obtained for the two periods appear similar. None of the explanatory variable has any significant impact on the volume of PMS consumed except income in the first period. Again the presence of serial correlation over the periods was common as a result first order autocorrelation model was used to improve on the OLS result.

The co-efficient of the variables are in their elasticities thus this implies that the price of PMS is inelastic. It therefore implies that quantity consumed is not determined by price conforming to economic theory.

The hypothesis that the withdrawal of subsidy has no significant impact on the domestic consumption of PMS holds.

\section{Summary, Conclusion and Recommendation Summary:}

This study highlighted the fundamental problems confronting the Nigeria economy and centred mainly on empirically determining the impact of subsidy withdrawal on domestic consumption of petroleum products PMS

(Premium Motor Spirit) from 1977-1997.

The empirical findings reveal that the price of PMS is not a significance determinant of the quantity consumed. Based on 
the economic theory, the findings prove PMS an inelastic good. Therefore, the consumption of PMS is not responsive or sensitive to price change.

\section{Conclusion:}

Arising from the above analysis the increase in prices of petroleum products over the years has influenced the prices of goods and services which tends to be bias upwards resulting in the increase in the general price level in the Nigerian economy. The demand being inelastic and is a fundamental input into the production process. However, increases in price of petroleum products will definitely increase the revenue base of the government and the marketers, and impoverish the consumers. This will send negative shocks to the economy.

\section{Recommendation:}

In the light of the findings of this study policies aimed at the followings will help ameliorate the negative effects of increase in prices of petroleum products.

(i) Government, Producers, Consumers, and Labor Unions should agree on time horizon on which price of these products could be revisited. A ten-year period is recommended to suit a long-range development-planning model.

(ii) Producers should be encouraged with generous incentives so as to be able to expand their scale and bring in the inassessable wells, thereby increasing the nation's reserves.

(iii) Much as the Nigerian government is faced with severe balance of payment (BOP) problems, the solution cannot be solved by solely concentrating on oil price increase annually. The diversification of the economy base is essential to address the BOP issues. A continuous petroleum product price increase 
will definitely take the good out of the reach of many consumers. This could result in adverse consequences such as inflation, unemployment, low productivity, deforestation and greenhouse effect and exacerbate the global warming trend.

(iv) There is the need to encourage the private sector to venture into both the upstream and down stream sector of the petroleum industry. The aim is to ensure a fair competitive price for the products.

(v) The present practice of importing refined petroleum products should be halted since this practice drains the country's hard earned foreign exchange, creates employment abroad, unemployment at home and discouraging local investors from investing in the petroleum sub sector of the economy.

\section{References}

Anyanwu, J.C. (1993): Monetary Economics Theory, Policy And Institution. Onitsha: Hybrid Publishers LTD.

Anyanwu, J.C. Dmowho,D. Hassan, O. Oyefusi, S.A (1997). The Structure of Nigerian Economy (1960-1997). Nigeria: Joanne Education Publishers.

CBN Statistical Bulletin. .7 ( 2). 1996/1997

CBN. (various years) Annual Reports and Statement of Accounts.

Dominick, S. (1982) Schaum's Outline of Theory And Problems of Statistics and Econometrics. London: Mc Graw-Hill Books.

Fadhill, J.A.(1990). OPEC and International Oil Industry: A changing structure: Oxford. Oxford University Press.

FOS (1996). "Review Of The Nigerian Economy 1995". Lagos: Government press.

Gujarati, D.(1984). Basic Econometrics. London: Mc Graw-hill. Iioeje, O.C.(19930. "Effects of Fuel Prices On Internal 
Substitution". Conference proceedings on energy pricing and national development. Lagos: Government Press

Iwayemi, A. (1993). "Effect of Energy Pricing On Energy Efficiency and Environment". Conference proceeding on energy pricing and national development, national committee of the world energy council. Lagos: Government Press.

Iyoha, M.A. (1996). "Macroeconomic policy management of Nigeria's external sector in the post-SAP period". The Nigerian Journal of Economic and Social Studies. Ibadan. 38(1,2 and 3) OUP

Jaja, M.T. (1997). "Strategies for eliminating adulteration of petroleum products in Nigeria" CBN Bullion 21(3) CBN Publication.

Koutsoyiannis, A.(1997). Theory of Economics. London: Macmillan.

NNPC "Investment Opportunities in Oil, Gas and Petrochemical Industries in Nigeria". Lagos NNPC: Publication.

NNPC. "The fact of the matter, appropriate pricing of petroleum products". Lagos: NNPC Publications.

Ojo, M.O. and Adebusuyi, B.S. (1996). "The state of the Nigerian petroleum industry, performance, problems and outstanding issues". CBN. Economics and Financial Review..34(3) CBN. Publication.

Uduebor, M.A. (1994). "Determining the Price of Petroleum Products in Nigeria and the Issue of Price Subsidy". CBN. Economic and Financial Review. 32(1) CBN Publication. 